Original Research

\title{
Improving Self-Protection Knowledge Against Sexual Abuse by using Dreall Healthy and Animation Video
}

\section{Adelia Pradita, Arie Kusumaningrum and Jum Natosba}

Nursing Science Study Program, Faculty of Medicine Sriwijaya University, South Sumatera, Indonesia

\begin{abstract}
Introduction: The number of child sexual abuse cases in Indonesia are still high, including in Ogan Komering Ilir Regency, South Sumatera. One of the preventive effort that can be practiced is teaching them about children selfprotection knowledge from sexual abuse through sexual education using appropriate methods and media, such as watching animated video and dreall healthy. The aim of this research was to determine difference in dreall healthy and animated video about sexual education toward children self-protection knowledge from sexual abuse.
\end{abstract}

Methods: This research was a quantitative study and use quasi experiment design with pretest-postest group. Samples in this research were 40 children in dreall healthy group and 37 children in the animated video group, the samples were taken using purposive sampling technique. The data were collected by using questionnaire and data analysis was using paired t test and independent t test.

Results: This research showed that there was difference in children selfprotection knowledge from sexual abuse before and after sexual education with dreall healthy and animated video with $p$ value $0.000(\alpha \leq 0.05)$ and there was difference in children self-protection knowledge from sexual abuse between dreall healthy and animated video with $p$ value $0.014(\alpha \leq 0.05)$.

Conclusion: Sexual education with dreall healthy is more effective to increase children self-protection knowledge because it can stimulate the children's brain nerves so that their memory could be better. It was expected that parents, public health center staffs, and counselor in schools be able to provide sexual education as early as possible to the children.

\section{ARTICLE HISTORY}

Received: March 12, 2018

Accepted: Dec 18, 2018

\section{KEYWORDS}

sexual education; sexual abuse; self-protection; dreall healthy; animated video

\section{CONTACT}

Jum Natosba

$\triangle$ jumnatosba_bayd@yahoo.co.id $\ggg$ Nursing Science Study Program, Faculty of Medicine Sriwijaya University, South Sumatera, Indonesia

Cite this as: Pradita, A., Natosba, J., \& Kusumaningrum, A. (2018). Improving Self-Protection Knowledge Against Sexual Abuse by using Dreall Healthy and Animation Video. Jurnal Ners, 13(2), 178-183. doi:http://dx.doi.org/10.20473/in.v13i2.7824

\section{INTRODUCTION}

Sexual violence is any act of coercion of sexual intercourse in a way that is unnatural and disliked by a child, coercion of sexual intercourse with another person for a specific commercial or purposeful purpose (Maharani et al., 2015). Based on data from the National Children's Alliance (NCA) there was an increasement in the number of sexual violence cases against children from 2014 to 2016. In 2014 the number of sexual violence cases against children reached to 205,438 cases. In 2015 the number of sexual violence cases against children increased to 206,768 cases and in 2016 the number of cases increased to 215,425 cases (National Children's Alliance, 2016).
In Indonesia, according to data from the National Commission for Child Protection, it shows that in 2015 , cases of violence against children increased by 2,898 reports, $62 \%$ of which were sexual crimes and many unreported incidents (Research Center of DPR RI Expertise Agency, 2016). Based on the data of the Regional Child Protection Commission of Indonesia, Palembang, in the period of January to August 2016, had 20 cases of which were mostly cases of sexual violence against children, such as fornication and rape.

Based on the data from the South Sumatera Provincial Women's Empowerment and Child Protection Agency, Ogan Komering Ilir District is included in 10 districts with the highest number of cases of violence against women and children. Five 
districts with the number of cases of violence against women and other children are Musi Banyuasin district, Empat Lawang, Banyuasin, Pali and Muara Enim. Based on data from the Office of Women Empowerment and Child Protection of Ogan Komering Ilir District, the number of cases of violence and sexual abuse in 2016, including child abuse, amounted to 24 cases.

The role of the country in overcoming violence against children, including child sexual abuse in Indonesia, is the establishment of the Indonesian Child Protection Commission, ratifying the Convention on the Rights of the Child, formulating laws on child protection, and forming a child-friendly city (Yarrini, 2014). In 2016, UNICEF collaborated with the World Health Organization (WHO) and other international partners to develop a technical package entitled 'INSPIRE: Seven strategies to end violence against children including sexual violence, which is implementation and enforcement of laws, Norms and values, Safe environments, Parent and caregiver support, Income and economic strengthening, Response and support services, education and lifeskills (UNICEF, 2017). Some efforts that have been made by the Indonesian Child Protection Commission (KPAI) to prevent violence and sexual harassment of children are by forming the SELARAS program (Save and Protect Children from Sexual Violence), establishing an integrated child protection system, and building a city that was worthy for children (Erlinda, 2016).

Based on data from Nugraha and Wibisono (2016), the high number of sexual violence cases was due to the lack of public knowledge about what can be taught to children to prevent acts of sexual violence and parents still feel taboo in providing sexual education to children, so that children have not gotten knowledge about sexual violence and how to protect themselves from sexual violence.

Prevention of sexual violence in children can be done by building a defend mechanism to provide knowledge and appreciation of their valuable body parts through the early sexual education (Erlinda, 2016). Sexual education can be provided to the children in the form of knowledge of self-protection skills of the occurrence of sexual abuse (Jatmikowati, Angin, \& Ernawati, 2015). One study conducted by Jatmikowati et al (2015) shows that the subject matter of early childhood sex education includes themes: (1) Me and my body; (2) Me and my clothes; (3) Families and people around me; and (4) How to care for and keep the body.

Sex education can be done with an open attitude and in a relaxed atmosphere. In providing sexual education, methods and learning media need to be considered in order to achieve the goals of sexual education (Iskandar, Suhadi, \& Maryati, 2014). The choice of learning methods and media, including providing sexual education, is adjusted to the age of the child. Learning methods and media that can be provided for early childhood are audio visual media such as animated videos and image media in the form of single images or images that are radiant or a set of images that are interconnected with one another (Zaman \& Eliyawati, 2010).

Dreall Healthy is a form of puzzle game designed with a background that specifically contains content about health. Dreall healthy games can motivate and stimulate children's thinking patterns in applying health values contained in the game background (Rezky \& Hardianto, 2012). In addition, puzzles are called educational games because in puzzle games there are educational elements which can train and improve children's memory, introduce children with various images, colors, and character's forms that are loved by children (Soraya \& Rohmah, 2012).

Animated video is one of the learning media that can be provided for early childhood (Zaman \& Eliyawati, 2010). Animated video is one of the methods and media that has been used in providing sexual education to children released by the Ministry of Women's Education and Child Protection and supported by UNICEF in 2014 through youtube. The video contains information about how to protect children from violence and sexual abuse. The effectiveness of animated video media in health education has been proven in a study that stated that animated videos effectively improve children's knowledge (Andriany, Novita, \& Aqmaliya, 2016).

Animated videos and educational games are media and methods that can be used to provide learning and sexual education to children. However, in the implementation, both methods and media have not been maximally realized by the community where there was still lack of knowledge of the community about what can be taught to children in preventing acts of sexual violence so that people have less knowledge about what can be taught to children in preventing the occurrence of sexual violence acts (Rilianti \& Ima, 2011; Notoatmodjo, 2012).

Based on the above background, researchers were interested to conduct a research focusing on the difference between the use of dreall healthy and animation videos about sexual education towards child's self-protection knowledge from sexual abuse. The purpose of this study was to determine differences in dreall healthy and animated video about sexual education toward children selfprotection knowledge from sexual abuse.

\section{MATERIALS AND METHODS}

This research was a quantitative research with quasi experiment design with pre-test and post-test group. The sample of this study were 77 respondents obtained from the population of 1-2 grade children (age 6-7 years old) that collected on 30 March 2017, with total number of 1692 children in Kayuagung sub-district. The sampling technique used was purposive sampling with inclusion criteria, namely; those 1-2 graders of elementary school (age 6-7 years) who were physically and mentally healthy, willing to be research respondents, able to read, 
have not received sexual education or information about child's self-protection yet, originally from Kayuagung, and interested in playing puzzles and watching animation videos according to their respective groups. This research was conducted at two elementary schools in Kayuagung. The sample was divided into 2 groups; dreall healthy intervention group and animation video intervention group.

The data collection tools used were questionnaire and observation sheet. Questionnaire was consisted of open-ended questions. The questionnaire used was adapted from the research of Jatmikowati et al., (2015), which was modified by researchers. The questionnaire contains material about (1) Me and my body; (2) Me and my clothes; (3) Families and people around me; and (4) How to care for and keep the body. The questionnaire consisted of 25 questions that have been proven valid and reliable. The validity test was carried out by researchers in April 2017. Validity test was using the Pearson Product Moment test. Validity test results showed that there were 25 valid questions with $r$ arithmetic $>\mathrm{r}$ table $(0.5760)$, and reliability test results showed that 25 questions were reliable with Cronbach's alpha value $0.755(>0.6)$.

The study was conducted in the classroom according to the intervention group in 1 day which was consisted of 2 sessions. Session 1 for dreall healthy interventions. Before intervention, researchers and assistants distributed pre-test sheets. Researchers and assistants interviewed participants using a 20-minutes pre-test sheet. Then intervening dreall healthy games for 28 minutes and ended with an interview process using a post-test sheets. Session 1 was carried out for 80 minutes. Next, session 2 is an animation video intervention. Before intervention, researchers and assistants distributed pre-test sheets. Researchers and assistants interviewed participants using a 20 minutes pre-test sheet. Then the next intervention, watching the animated video, was held for 13 minutes and ended with the interview process using the post-test sheets. Session 2 was conducted for 60 minutes.

The data collection procedure started from performing administrative procedures in the form of research implementation permission and distribution of informed consent sheet to the respondents' parents. Furthermore, researchers and research assistants undertook preparation phase, which was environmental preparation such as lighting and noise, places and respondents. Data collection was conducted before and after the intervention was conducted, and the observation of the research was conducted during the intervention process. Data analysis used was univariate and bivariate analysis. Univariate analysis describes the characteristics of respondents, and bivariate analysis used paired $t$ test and independent $t$ test using SPSS
16 software. This research has been in accordance with the research standards and has meets ethical criteria consisting of informed consent, anonymity, confidentiality, beneficiary and justice.

\section{RESULTS}

The characteristics of Respondents based on their sex, in the dreall healthy group there were 40 respondents, consisted of $52.5 \%$ female and $47.5 \%$ male, in the animated video group there were 37 respondents, consisted of $45.95 \%$ female and 54 , $05 \%$ of male. From both groups, there were $50,65 \%$ male respondents and $49,35 \%$ female respondents.. All respondents were 7 years old. All respondents came from Kayuagung, Ogan Komering Ilir. All of the respondents have not had any information and any experience of sexual education about child's selfprotection knowledge against sexual violence.

Before the analysis was conducted, the researcher first performed the data distribution test by using normality test. The normality test in this study used the shapiro-wilk test, because the number of samples for each group was less than 50 samples (Dahlan, 2014). Normality test results showed the obtained $\mathrm{p}$ value in dreall healthy group during pre-test was 0.159 , and at post-test was 0.066 . In the animation video group, the $p$ value of the pre-test value was 0.131 , and the post-test was 0.107 . Thus, dreall healthy group data and animation video during pre-test and post-test were normally distributed ( $p$ value $\geq 0.05$ )

The average score of children's self-protection knowledge against sexual abuse before given sexual education through dreall healthy was 18.32 (SD \pm 1.607), and the mean score after given sexual education was 22.60 (SD \pm 1.499 ) which means that there was a significant improvement in respondents' knowledge of self-protection after being given sexual education through dreall healthy (table 1).

Based on the statistical analysis, it was found that there was a significant difference in score of children's self-protection knowledge against sexual abuse before and after sexual education through dreall healthy with $p$ value $0.000(\alpha \leq 0.05)$. Based on the observation data, the respondents who played while learning, in this case played the puzzle, were more interested and more excited in preparing the puzzle pieces. In addition, respondents were very enthusiastic and curious about the results of the arrangement of the puzzle; therefore, respondents were more focused in viewing and reading the contents of the puzzle (table 1).

The average score of child's self-protection knowledge against sexual abuse was 18.76 (SD \pm 1.754), and the mean score after given sexual education was 22.27 (SD \pm 1.610 ) which also means that there was a significant improvement in respondents' knowledge after being given sexual education through video animation (table 1). 
Table 1. Differences in Score of Child's Self-Protection Knowledge against Sexual Abuse Before and After Given Sexual Education through Dreall Healthy

\begin{tabular}{|c|c|c|c|c|c|c|c|c|c|c|}
\hline \multirow[t]{2}{*}{ Groups } & & \multirow[t]{2}{*}{$\mathbf{n}$} & \multirow[t]{2}{*}{ Mean } & \multirow[t]{2}{*}{ SD } & \multirow[t]{2}{*}{ Min-Max } & \multicolumn{2}{|c|}{$95 \% \mathrm{CI}$} & \multirow[t]{2}{*}{$\mathbf{t}$} & \multirow[t]{2}{*}{ df } & \multirow[t]{2}{*}{$P$ value } \\
\hline & & & & & & lower & Upper & & & \\
\hline \multirow{2}{*}{$\begin{array}{l}\text { Dreall } \\
\text { Healthy }\end{array}$} & Pre-test & & 18.32 & 1.607 & 15.22 & 17.18 & 18.84 & -20.480 & 39 & 0.000 \\
\hline & Post-test & 40 & 22.60 & 1.499 & 19.25 & 22.12 & 23.08 & & & \\
\hline \multirow{2}{*}{$\begin{array}{l}\text { Animation } \\
\text { video }\end{array}$} & Pre-test & & 18.76 & 1.754 & 15.22 & 19.17 & 19.34 & -16.125 & 36 & 0.000 \\
\hline & Post-test & 37 & 22.27 & 1.610 & 1925 & 21.73 & 22.81 & & & \\
\hline
\end{tabular}

Table 2. Differences in Average Score of Child's Self-Protection Knowledge against Sexual Abuse between Dreall Healthy and Animation Groups.

\begin{tabular}{clcccc}
\hline \multicolumn{1}{c}{ Variable } & Intervention & n & Mean & SD & P value \\
\hline Knowledge & Dreall Healthy & 40 & 4.28 & 1.320 & 0.014 \\
& Animation Videos & 37 & 3.51 & 1.325 \\
\hline
\end{tabular}

Based on the statistical analysis, it is also known that there was a significant difference in score of children's self-protection knowledge against sexual abuse before and after sex education through animated video with $p$ value $0.000(\alpha \leq 0.05)$. Based on observation data, children became very interested in watching animated videos, especially in the form of cartoons. Video with colorful display, with cartoon pictures that the respondents liked, and accompanied by sound, made respondents became more interested in watching the animation video. Therefore, the process of delivering information was more easily accepted by respondents (table 1 ).

Based on the table 2, it can be seen that the difference of the average score of child's selfprotection knowledge against sexual abuse with dreall healthy intervention was 4.28 ( $S D \pm 1.320$ ). Meanwhile, the difference of the average score of child's self-protection against sexual abuse with the animation video intervention was 3.51 (SD \pm 1.325 ). From the result of the statistical analysis, it can be concluded that there was a significant difference on child's self-protection knowledge against sexual abuse between those who were taught se education through the dreall healthy and through animation video with $\mathrm{p}$ value $0.014(\alpha \leq 0.05)$. The difference of dreall healthy group average score was greater than that of animation videos groups. Therefore, it can be concluded that dreall healthy is more effective in increasing the child's knowledge about selfprotection against sexual abuse.

\section{DISCUSSION}

The media play an important role in practice, policy, and public perception of child sexual abuse, in part by the way in which news stories are framed (Weatherreda, 2015). Based on research conducted by Walsh, Zwi, Woolfenden, and Shlonsky, (2015), it shows that school-based sexual harassment prevention programs using video media and game methods are effective in increasing participants' skills in protective behavior and knowledge about the concept of preventing sexual harassment.

The result of statistical test with paired t-test shows that there was a significant improvement in respondents' knowledge after being given sexual education through dreall healthy. This is in accordance with the results of research conducted by Hariyanto dan Sumini (2016) which revealed that nutrition education by using the media of balanced nutrition 'tumpeng' puzzle in kindergarten managed to improve the child's knowledge about balanced nutrition.

Dreall Healthy is a form of puzzle game, but with different pieces of puzzle pieces, that is hexagonal shape (Rezky \& Hardianto, 2012). Puzzle game is a form of educational game for elementary school age children called the skill game. Proficiency games are all forms of games and activities that require proficiency in controlled hands and eyes use (Dorothy, 1985, quoted by Simon, Hartati, and Arsilah, (2007). Based on the data from Trisyana and Reza (2013), by playing puzzles the child's thinking and cognitive abilities will increase because when playing puzzle children will train their brain cells to develop their thinking skills and concentrate on completing pieces of the puzzle.

There was a significant difference in score of children's self-protection knowledge against sexual abuse before and after sexual education through dreall healthy. This result is supported by research conducted by Nurvita (2014) which explains that the puzzle game can develop the cognitive aspects of children in which children will be more interested to learn and to understand the contents of the puzzle. Based on observations, respondents who were playing while learning, in this case, playing puzzles will be more interested and more enthusiastic in compiling the puzzle pieces. In addition, respondents were very enthusiastic and curious about the results of the puzzle arrangement so that the respondents were more focused on seeing and reading the contents of the puzzle.

The result of statistical test with paired t-test shows that there was a significant improvement in respondents' knowledge after being given sexual education through video animation because in the delivery of messages through video animation make use of the visual and 
audio aspects so as to make it easier in storing information (Noviyanto, Juanengsih, \& Rosyidatun, 2015). The colorful display of videos, using animated images and accompanied by sound make respondents more interested to watch the animated video shows so that the process of delivering information will be more easily accepted by respondents. This result is in accordance with a research conducted by Andriany et al., (2016) with the results of research showing the increased knowledge about dental and oral health on respondents after given counseling through animation media.

It is also known that there was a significant difference in score of children's self-protection knowledge against sexual abuse before and after sex education through animated video. This is in accordance with the statement of Andriany et al., (2016) that the improvement of oral and dental health knowledge due to animated cartoon animation media is able to stimulate children's curiosity and their interest in what they learn, thus, the purpose of the counseling media can achieve optimal results.

From the result of the statistical analysis, it can be concluded that there was a significant difference on child's self-protection knowledge against sexual abuse between those who were taught education through the dreall healthy and through animation video. The difference of dreall healthy group average score was greater than that of animation videos groups. Therefore, it can be concluded that dreall healthy is more effective in increasing the child's knowledge about self-protection against sexual abuse.

Dreall healthy games gives an effect in improving child's self-protection knowledge against sexual abuse because puzzle games are more interesting and more fun, so children are more likely to receive the information given (Hikmawati, Yasnani, \& Sya'ban, 2016). This is supported by research conducted by Riadi dan Supriyono (2014). Their results showed that puzzle media have successfully increased the students' learning outcomes in each cycle and have made the students' achieve their success indicators.

Video is one of the tools in giving or delivering messages (Notoatmodjo, 2012). The use of animated video media in delivering health education messages makes it easier to store information on cognitive structures because of the presentation of information that utilizes visual and audio aspects. In accordance with the theory that was put forward by Piaget about cognitive learning theory, information is more meaningful in student memory and stored in long term memory in the right brain, therefore presentation of information needs to utilize visual and audio aspects (Noviyanto et al., 2015).

The results of research conducted by Lubis (2016) showed that the audio visual method is more effective in improving knowledge of child dental caries care in the area of Wonosegoro II Community Health Center. Based on the data from Miftahusaadah, (2016), video were influential and useful in increasing knowledge about the selection of snack foods for students at SD 01 Gayamdompo, Karanganyar District, Karanganyar Regency. This statement is supported by the results of the Sinor (2011) which states that animated cartoons are more effective in conveying messages of oral health education compared to conventional methods in students at the Upper Terengganu School.

However, at the time of the animation video intervention in observation data, not all children could focus on the animation video because many things could make children distracted while watching the video. Therefore, not all children were able to receive information from the video. This is supported by the theory from Kustandi dan Sutjipto (2013) which explained that, when the video was continuously played, not all children can follow the information conveyed through the video. Both methods are equally attractive to children in receiving learning. According to the theory proposed Khadijah (2016), one of the methods in developing children's cognitive side is the method of play, because learning that does not use game on it, has not yet been able to improve cognitive ability (Olii, 2013).

\section{CONCLUSION}

Dreall healthy and animated video can enhance the knowledge of children's self-protection from sexual abuse where dreall healthy is more effective than animated video. Sexual education with dreall healthy is more effective to increase children self-protection knowledge because it can stimulate the children's brain nerves so that their memory could be better. It was expected that parents, public health center staffs, and counselor in schools be able to provide sexual education as early as possible to the children. For further researchers, it is expected that further research can create more interesting media for children and can involve parents directly in providing sexual education to children so that parents can more easily convey sexual education information and not be taboo on sexual education to children.

\section{ACKNOWLEDGEMENT}

We thank to Headmaster of SDN 1 and 17 Kayuagung for licensing of research sites.

\section{REFERENCES}

Andriany, P., Novita, C. F., \& Aqmaliya, S. (2016). Perbandingan Efektivitas Media Penyuluhan Poster dan Kartun Animasi terhadap pengetahuan Kesehatan Gigi dan Mulut. Journal of Syiah Kuala Destistry Society, 1(1), 65-72.

Dahlan, M. S. (2014). Statistik untuk Kedokteran dan Kesehatan. Jakarta: Epidemiologi Indonesia.

Erlinda. (2016). Upaya Peningkatan Perlindungan Anak dari Bahaya Kekerasan, Pelecehan dan Eksploitasi. Jakarta: Komisi Perlindungan Anak Indonesia.

Hariyanto, \& Sumini. (2016). Pengaruh Pendidikan Gizi Menggunakan Media Puzzle Tumpeng Gizi Seimbang terhadap Pengetahuan Gizi Anak Taman Kanak-Kanak. Sain Med, 8(1), 26-31.

Hikmawati, Z., Yasnani, \& Sya'ban, A. R. (2016). 
Pengaruh penyuluhan dengan media promosi puzzle gizi terhadap perilaku gizi seimbang pada siswa kelas $v$ di sd negeri 06 poasia kota kendari. Universitas Halu Oleo.

Iskandar, H., Suhadi, \& Maryati. (2014). Pengaruh Modelling Media Video Cuci Tangan terhadap Kemampuan Cuci Tangan Pada Siswa Kelas 4 Di SD Wonosari 02 Mangkang Semarang. Jurnal Ilmu Keperawatan Dan Ilmu Kebidanan.

Jatmikowati, T. E., Angin, R., \& Ernawati. (2015). Model dan Materi Pendidikan Seks Anak Usia Dini Perspektif Gender Untuk Menghindarkan Sexual Abuse. Cakrawala Pendidikan, 24(3).

Khadijah. (2016). Perkembangan Kognitif Anak Usia Dini. Medan: Perdana Publishing.

Kustandi, C., \& Sutjipto, B. (2013). Media Pembelajaran Manual dan Digital Edisi Kedua. Bogor: Ghalia Indonesia.

Lubis, F. S. (2016). Perbedaan Pendidikan Kesehatan Menggunakan Metode Ceramah dan Audio Visual terhadap Tingkat Pengetahuan dan Sikap Perawatan Karies Gigi Anak di Wilayah Puskesmas Wonosegoro II. Universitas Muhammadiyah Surakarta.

Maharani, F. D., Setia, F., Ranadireksa, A., Raharjo, F. D., Simatupang, D. F., Susilowati, A., \& Rosmiati. (2015). Anak Adalah Anugerah: Stop Kekerasan Terhadap Anak. Jakarta: Kementerian Komunikasi dan Informasi Republik Indonesia.

Miftahusaadah. (2016). Pengaruh Pendidikan tentang Makanan Jajanan Menggunakan Media Video Digital terhadap Pengetahuan Siswa Di SDN 01 Gayamdompo Kecamatan Karanganyar Kabupaten Karanganyar. Universitas Muhammadiyah Surakarta.

National Children's Alliance. (2016). NCA National Statistics - Statistical Report 2016. Retrieved January 30, 2016, from http://www.nationalchildrensalliance.org/ (Accessed: October 22, 2017).

Notoatmodjo, S. (2012). Promosi Kesehatan dan Perilaku Kesehatan. Jakarta: Rineka Cipta.

Noviyanto, T. S. H., Juanengsih, N., \& Rosyidatun, E. S. (2015). Penggunaan Media Video Animasi Sistem Pernapasan Manusia Untuk Meningkatkan Hasil Belajar Biologi. Edusains, 7(1).

Nugraha, B. D., \& Wibisono, S. (2016). Adik Bayi Datang Dari Mana? Jakarta: Noura Books.

Nurvita, F. (2014). Permainan Puzzle Berpengaruh Terhadap Perkembangan Kognitif Pada Anak Usia
Dini Di TK Pertiwi Karanglor, Manyaran, Wonogiri Tahun Pelajaran 2013/2014. Universitas Muhammadiyah Surakarta.

Olii, H. U. (2013). Meningkatkan Kemampuan Kognitif Anak Melalui Alat Permainan Edukatif Di TK Sis AljufriI 1 Tatura Palu. Universitas Tadulako.

Pusat Penelitian Badan Keahlian DPR RI. (2016). Kondisi sosial ekonomi dan kekerasan seksual pada anak, VIII(9).

Rezky, M., \& Hardianto, D. P. (2012). V-HASOP (Villages Healthy School Programmes By Using Dreall Healthy): Penanaman Pendidikan Kesehatan Melalui Permainan Dreall Healthy Pada Anak Usia Sekolah di Pedesaan. Padang.

Riadi, M. E., \& Supriyono. (2014). Penggunaan Media Puzzle Untuk Meningkatkan Hasil Belajar Siswa Pada Tema Lingkungan Kelas II SDN Jajartunggal III Surabaya. JPGSD, 2(2).

Simon, R., Hartati, T., \& Arsilah. (2007). Model Permainan Di Sekolah Dasar Berdasarkan Pendekatan DAP (Developmentally Appropriate Practice). Universitas Pendidikan Indonesia, Bandung.

Soraya, A., \& Rohmah, N. (2012). Pengaruh Pendidikan Kesehatan Dengan Media Puzzle Terhadap Kemampuan Mencuci Tangan Pada Anak Usia Sekolah (6-12) Tahun Di Kecamatan Jelbuk Kabupaten Jember. Universitas Muhammadiyah Jember.

UNICEF. (2017). Preventing and Responding to Violences Against Children and Adolescents: Theory of Change. New York: UNICEF.

Walsh, K., Zwi, K., Woolfenden, S., \& Shlonsky, A. (2015). School-based education programmes for the prevention of child sexual abuse. The Cochrane Collaboration, (4). https://doi.org/10.1002/14651858.CD004380.p ub3.

Weatherreda, J. L. (2015). Child Sexual Abuse and the Media: A Literature Review. Journal of Child Sexual Abuse, 24(1), 16-34. https://doi.org/10.1080/10538712.2015.97630 2

Yarrini, D. S. (2014). Peran Negara Dalam Upaya Mengatasi Tindak Kekerasan terhadap Anak. Universitas Islam Negeri Syarif Hidayatullah.

Zaman, B., \& Eliyawati, C. (2010). Media Pembelajaran Anak Usia Dini. Universitas Pendidikan Indonesia. 